\title{
Study on Basic Education of University Computer Based on Innovation Curriculum
}

\author{
Yangqing Zhu \\ School of Electronic and Information Engineering, Foshan University, Foshan City, Guangdong \\ Province, China
}

zhuyangqing_830516@163.com

\begin{abstract}
Keywords: University Computer Basic Education; Innovation Curriculum; Comprehensive Ability Training; Teaching Reform.
\end{abstract}

\begin{abstract}
The innovation of curriculum is the core to improve education quality in universities; innovative curriculum construction is an important starting point to promote higher education reform. The purpose is to cultivate students' computer knowledge, technology and application ability for servicing in the students employment and professional itself, to create more innovative and entrepreneurial talents as teaching objectives. The paper studied teaching reform guiding principle of service to the teaching objectives, analyzed connotation and construction principle of innovation courses. In combination with the economic management major in our university, designed the innovation curriculum of general education and professional courses combined, carried out teaching reform practices of the flipped class, network learning evaluation, attempted to cultivate students' ability to solve the problems of entrepreneurship and innovation, provide a reference path for the reform of university computer basic education in China.
\end{abstract}

\section{Introduction}

At present, many colleges and universities teachers thought that computer basic course is to teach students how to use the computer, so that the computer discipline formed a "narrow tools" theory, as in [1]. At the same time, the computer basic courses were taken as a common course of all professional students, various professional set up the same content of courses, courses setting up, courses structure, course content and teaching methods are unified, so that students' creative ability and practical ability were relatively weak.

How to position computer basic teaching and reform course contents to adapt the social development are the important challenge for the university computer basis education. Combining with professional, to cultivate students' innovation, entrepreneurship and comprehensive ability has become the direction of teaching reform of computer basic course in universities. Studied the computer basic education innovation courses construction based on general education and combining with professional courses in the major of economic management, reformed teaching strategies and learning evaluation, achieved good teaching results. Here, let's discuss above problems, to improve the university computer basic course teaching reform.

\section{The Connotation of Innovation Courses}

Curriculum is the main carrier of the implementation of personnel training, all education and teaching contents of the university are almost all reflected in the curriculum. In essence, the quality of personnel training depends on the level and quality of the course. According to the requirements of transformation and upgrading of industrial structure, colleges and universities should construct a system of knowledge structure to adapt the industrial structure, cultivate the talents of innovation quality, knowledge and comprehensive ability to meet the requirement of knowledge economy age.

Innovative curriculum mainly includes innovation of curriculum concept, system innovation and content. The concept of curriculum innovation is to take the students as the present, and constantly promote the curriculum innovation and construction, provide all kinds of courses to meet the needs of students. The innovation of curriculum system should combine with the professional training goal and 
the students' future practical work content; ensure the systematicness and coherence of cultivating students' knowledge and comprehensive ability. Innovations of curriculum content is set up curriculum content according to the requirements of talent cultivation goal, meet the requirements of contemporary social development and in some way to lead the social development, and construct teaching mode based on the students' autonomous learning and interaction between teachers and students, as in [2].

\section{Principles of Construction Innovative Curriculum}

Colleges and universities should be according to their actual situation and economic development needs, under the guidance of advanced education thoughts, clear the overall goal of education and teaching, starting from the curriculum innovation and construction, carry out teaching reform practice, as in [3].

University computer basic education is geared to the computer education system of non-computer professional, scientific plan knowledge structure and course system of university computer basic education, explore the rules and methods of computer education, explore the effective ways for training college students' diverse thinking, the start point is to push the universities carry out the college computer teaching reform, curriculum construction and construction of stereoscopic teaching materials according to the different professional types and its application needs. Fig.1 showed the composition diagram of principles of construction innovative curriculum.

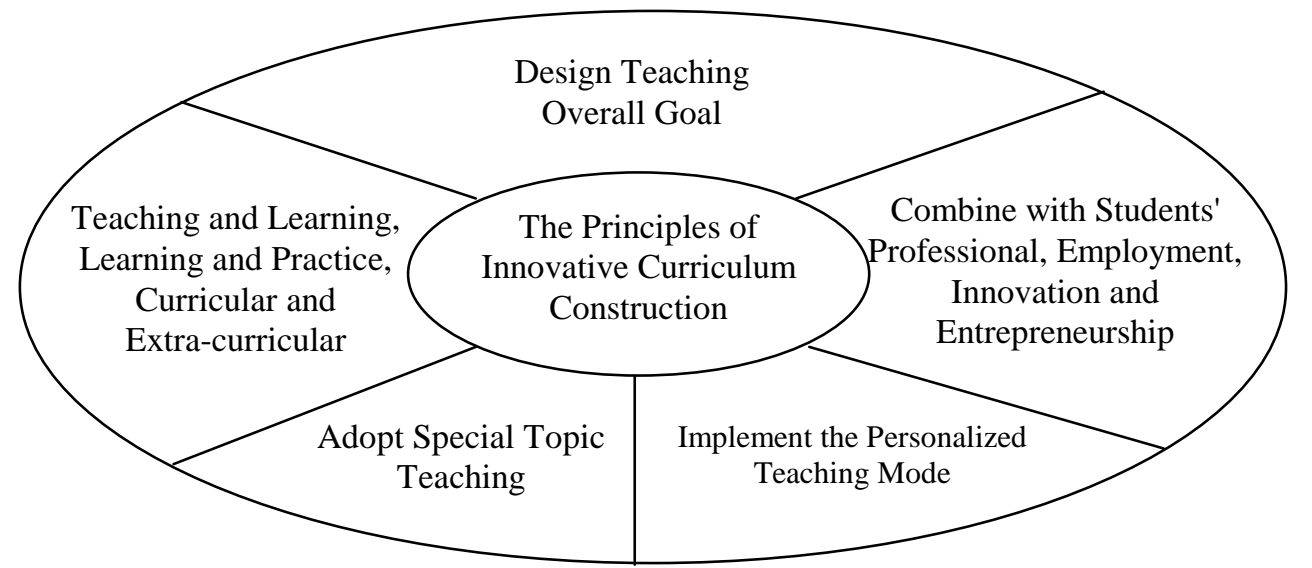

Fig.1 The Composition Diagram of Principles of Construction Innovative Curriculum

\subsection{Design Teaching Overall Goal}

The university computer basis teaching overall goal is to cultivate the students' computer knowledge, technology and application abilities for serving students' employment and professional it needs, to cultivate more innovation and entrepreneurial talents. The content of teaching is to cultivate the students' information literacy and the application ability as the main line, to carry out the research of university computer teaching reform, including understand the great contribution made by the application of information technology to the development of economy and society, understand information technology and humanities and social sciences mutual infiltration and cross fusion, understand and master the thinking path and methods for using computational thinking and computational tools to solve the problems in the field of professional, as in [4].

\subsection{Combine with Students' Professional, Employment, Innovation and Entrepreneurship}

In the curriculum construction and teaching implementation process, to reform the unified computer basic course contents in the university, fully consider how to combine with students' professional, innovation, entrepreneurship and employment. 


\subsection{Implement the Personalized Teaching Mode}

Take cultivating students' innovation, entrepreneurship and comprehensive solving ability as the core, using flipping the classroom and network teaching, to enable students to participate in teaching, fully reflect the personality of students, and cultivate students according to their characteristics.

\subsection{Adopt Special Topic Teaching}

Analyze the development of today's computer technology, design several topics, and teach a topic each class, to enable students to obtain a systematic knowledge of computers within a limited time, form effective framework of knowledge and the ability of solving problems.

\subsection{Teaching and Learning, Learning and Practice, Curricular and Extra-curricular}

Teaching and Learning, that is ,take encouraging students' autonomous learning as the goal, set up the ideas of teachers as the "guidance", "tutor" and "assistant" of students' autonomous learning, mobilize the enthusiasm of students' autonomous learning, construct an interactive classroom, strengthen the construction of information teaching means, construct the three-dimensional teaching carrier of paper, electronic and network teaching materials, provide the conditions for the students' autonomous learning. Learning and Practice, that is ,students not only learn the theoretical knowledge, but also to practice, carefully design teaching cases, enable the cases closely combined with the actual business, students analyze the cases and carry on practice, and improve students' practical ability and computing power. Curricular and Extra-curricular, that is, classroom is learning, extracurricular is also learning, encouraging students to participate university, provincial and national projects application, to participate subjects competition projects.

\section{Practice of Innovative Curriculum Construction}

Be in combination with economic management major, carried on the courses innovation construction of university computer basis education. After several discussion of computer basic education teachers and economic management professional teachers, thought that should reform the unified courses contents of computer basic education in the university, considered the characteristics of economic management professional, lay the foundation for future professional teaching and students' innovative and entrepreneurial work. The number of courses should not be too much, it is necessary to guarantee to enable students to learn a wide range of computer knowledge and the ability of data analysis, and pave the way for future professional course learning, namely through the university computer foundation curriculum construction to achieve economic management professional information technology general education and enhance training students' ability of solving problems with computer. According to the characteristics of the economic management specialty, designed two courses, Computer Technology and Civilization, and Excel in Business Applications.

\subsection{Computer Technology and Civilization}

Computer Technology and Civilization, is a general education curriculum, teach the advanced knowledge of computer technology, development, application, function, the famous entrepreneurial company, innovation and entrepreneurship characters and college students entrepreneurship deeds with IT. This course aims to cultivate students' innovative and entrepreneurial thinking, lay solid innovative ideas for subsequent courses, and enable students to think about how to combine professional knowledge with information technology in the professional course learning process, to carry out innovation, entrepreneurial learning and practice. This course includes eleven thematic content, they were computer basic knowledge, computer hardware system, programming language, operating system, computer network, data processing, multimedia, information security, artificial intelligence, e-commerce, a new generation of information technology. The teaching plan of the course was 32 hours.

\subsection{Excel in Business Applications}

Excel in Business Applications, combined with the actual operation of the enterprise, systematically analyze and teach data acquisition, data analysis tools, charts, data analysis results and 
so on, training students' ability of computing and computational thinking, enable students to understand each case meaning, expand students' learning and application space, and lay a solid foundation for students' future learning professional courses and work. This course mainly included Excel basic knowledge, excel in production application, excel in sales application, excel in financial management application, excel in human resources management application, excel in the management of national economy. To carry out teaching in the form of cases, train students' abilities of analyzing and solving practical problems. The teaching plan of the course was 36 hours.

\section{Teaching Strategies of the Courses}

\subsection{Efficient Integration of Flipped Classroom and Traditional Classroom Teaching}

The flipped classroom teaching is a teaching mode that students learn teaching contents in advance, and carry out discussion between teacher and students in the classroom. The flipped classroom teaching can cultivate students' independent thinking and creative thinking ability, as in [5]. Systematically and scientifically designed the course contents, carefully selected teaching cases, made micro video courses, students carried out self-study before class, summarize the study harvest and the existing problems, discussed in the class, to solve the encountered problems in the students' learning process and expand the students' knowledge. For more technical content, took the traditional classroom teaching mode that teacher taught key technical points and guided students to think and discuss. The combination of flipped classroom and traditional classroom teaching, greatly improved the efficiency and quality of classroom teaching, fully mobilized the initiative and enthusiasm of students learning.

\subsection{Network Teaching}

Using the network platform to carry out teaching, can issue teaching resources from time to time, guide students to self-study, carry out discussion between teachers and students, and timely solve students' encountered problems in the learning process, cultivate students' autonomous learning and collaborative learning ability, is conducive to the development of personalized student cultivation, as in [6]. Carried out the following network teaching practices.

Setting up course network learning platform. To establish teaching courses in the Blackboard platform, and establish QQ teaching group, such as Computer Technology and Civilization, Excel Teaching QQ teaching group, etc.

The construction of network teaching resources, included PPT teaching document, video courses, micro video, network testing questions database, answers to common questions. For example, computer hardware components, network assembly, artificial intelligence, cloud computing and other difficult to hands-on experimental content, online collection, editing, optimization of some video, formed video teaching resources to be conducive to students' learning.

The construction of the micro teaching resources. The so-called micro class that can be integrated with the conventional classroom teaching, for students' autonomous learning and teachers' professional development, on the integration of micro learning resources of formal and informal learning environment, play time is generally 5-10 minutes, as in [7]. To produce some micro video courses, such as mail merge, combination graphics, dynamic graphics, program management, simulation operations, exponential smoothing, regression analysis, etc. in the course of Excel in Business Applications.

Network learning interaction. Exchange was mainly around the subject of study, to solve the problems encountered in learning, as in [8]. Using blackboard teaching platform and QQ teaching group to discuss the previous lesson content and homework, put forward the main content of the next class, let the students to learn the content with textbooks, video courses, micro video resources, CNKI and related sites, form their own point of view, further discussed in class, to clear solving problems direction and thinking path. At the same time, according to the students' homework, independent testing and issued view in the network discussion process, analyzed students' learning effect and the 
stage, take some measures, implement personalized guidance and help for the students, make students to maximize the knowledge learned and solving problem ability within the stipulated time.

\subsection{Learning Evaluation Reform}

To construct a scientific and effective learning evaluation scheme, will bring great effect on students' learning, as in [9]. Learning evaluation scheme not only to assess students' learning of the basic content of the curriculum, but also to promote students' independent thinking, autonomous learning behavior and habits, influence their humanistic spirit, and cultivate students' innovative thinking and ability of application. Therefore, the process assessment and summary evaluation should be the same attention up.

Process Assessment Program. Design course usually grades accounted for a total score of 50\%, included class discussion 10\%, homework 30\% and network learning $10 \%$.

The evaluation of classroom discussion was carried out from the students' asking questions, answer questions and participate in the discussion. Homework assessment focused on training students' independent thinking and solving problems ability. Firstly, to construct no unified standard answer homework. For example, in the course homework of Computer Technology and Civilization, constructed the review of IBM company president's contribution, Internet business needs, college students' career planning, operation of the Internet system construction and operation mode, data value analysis homework. By completing this work, students can learn IT entrepreneurs and computer scientists' innovative and humanistic spirit, so as to cultivate students' innovative thinking and innovative ability. Secondly, pay attention to cultivating students' ability to solve practical problems, so homework should be closely integrated with the actual work. In the Excel in Business Applications course, designed teaching cases of production, sales, financial management and human resources management. By the completion of homework, students not only learnt the knowledge of Excel data analysis, but also understood the business process and the actual operation data processing, so as to improve the students' comprehensive analysis and solving problem ability.

Network Learning Evaluation. From the number of student's login network teaching platform, network discussion number and providing solutions, to evaluate students' network learning.

Summary Evaluation. The $50 \%$ of the total score of the course was summary evaluation score, summary evaluation was carried out by the computer examination system. Summary evaluation not only assesses basic content of students' learning, but also to promote students' comprehensive learning ability. In the exam questions, not only selected the knowledge content of computer theory and technology, but also designed some exam items of the dedication spirit and adventure spirit of some famous scientists and entrepreneurs, also included some items to be resolved the practical problems of company operation. To guide students to read textbook, related websites, magazines and other materials, promote students to learn extensive knowledge, enhance the comprehensive ability, and strengthen the cultivation of students' innovative thinking.

\section{Teaching Effectiveness}

In the innovation course construction and teaching reform, personnel talents cultivation effectiveness was great remarkable. Firstly, students' thinking has been expanded. After learning, students were able to look at the role of computer technology in various fields of the society from very broad perspective, thought about how to combine the computer technology with their future employment, entrepreneurship and learning professional course, students not only learnt computer knowledge and solving problem ability, also thought for their future. Secondly, Secondly, students' innovative and entrepreneurship ability have been improved. For example, some students carried out the design and development of online education platform, and provided the help for the mobile teaching of some courses. Some students used WeChat to sell their hometown products, not only to provide their own living expenses and learning costs, there also laid a certain savings for further entrepreneurship. Some students cooperated with the courier company, set up express service outlets in the university, provided express service in the spare time for teachers and students. 


\section{Conclusions}

Innovative curriculum was the core of improving teaching quality of Chinese universities, correct understanding of the connotation of innovative curriculum and construction principles were guarantee of construction and implementation of innovative courses. Innovative curriculum of colleges and universities should according the current courses, annually eliminated a part of all courses or reform about the course content, made the curriculum to meet the requirements of the era of knowledge economy, and in a certain extent can lead the social development. The innovation construction of the common course in universities must be combined with the relevant major.

\section{Acknowledgement}

This study was supported by 2014 annual innovative research project in Department of Education of Guangdong Province (No.2014GXJK109), 2014 annual liberal arts university computer teaching reform project in University Liberal Arts Computer Basic Teaching Guiding Committee of Ministry of Education of the People's Republic of China (No. 2014-B007).

\section{References}

[1]. Xingwei Hao, Yanbao Xu, Huaxian Wang. Investigation and Analysis on the Situation of Computer Teaching in Chinese Universities. China University Teaching, 2014(6):81-86.

[2]. Keming Yuan. University Curriculum Reform and Practice Based on the Cultivation of Innovative Talents. Journal of Educational Institute of Jilin Province, 2015, vol(31):37-38.

[3]. Wenxiao Zhang. Analysis of the Knowledge View for the Innovative Education Curriculum Dilemma in Higher Institutions. Chongqing Higher Education Research, 2016.4:65-71.

[4]. Liberal Arts Colleges Computer Basic Teaching Instruction Committee Document of Ministry of Education of the People's Republic of China. Notice on Carrying out Computer Teaching Reform Projects of Liberal Arts University. http://www.wkjsj.org/Article_Show.asp?ArticleID=275. 2014.3.

[5]. Liming Dong, Baochong Jiao. Research on the Teaching Application Model Based on the Concept of Flipped Classroom. E-education Research, 2014(7):108-113.

[6]. Dandan Yang, Lu Gan, Mei Zhou. The Application and Management of the Network Teaching Platform in Chinese Universities. Education and Vocation, 2015(7): 106-108.

[7]. Leming Liang, Qiaoqiao Cao, Baohui Zhang. Research on Micro Curriculum Design Model. Open Education Research, 2013(2):65-73.

[8]. Fengfang Shu, Chengling Zhao, Liyong Wang, Lei Huang, Fengfeng Duan. The Research of Interaction Properties in Online Class Based on the QQ Group. Modern Educational Technology, 2012(7): 83-88.

[9]. Lijun Tian. Theory and Application of Learning Evaluation. Northeast Normal University Press, 2015 